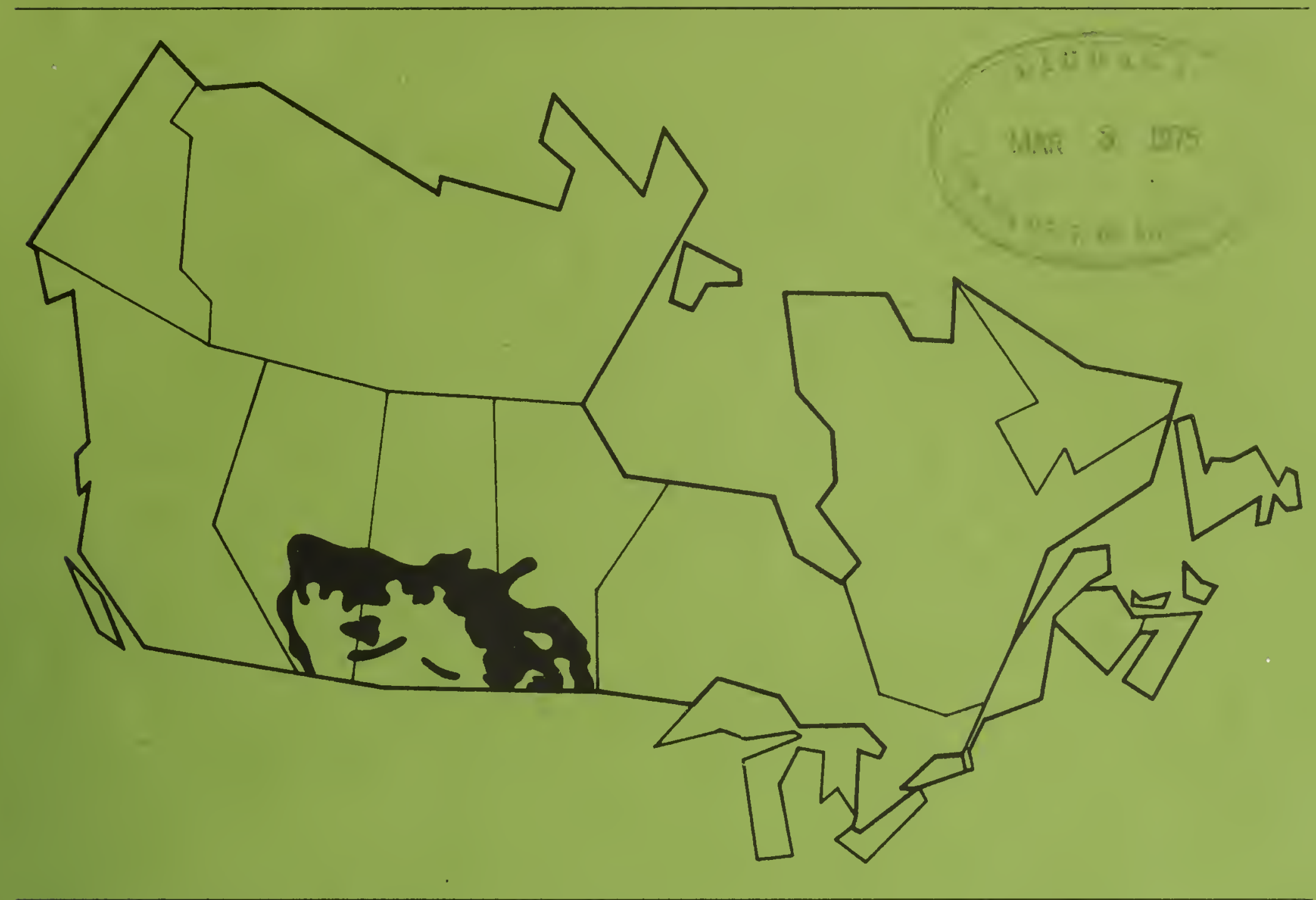

PASTURE PRODUCTION

AND UTILIZATION

in the aspen parklands

of Western Canada

Dth Agriculture

PUBLICATION 15461974 

Pub. 1546

1974

PASTURE PRODUCTION AND UTILIZATION

IN THE ASPEN PARKLANDS

OF WESTERN CANADA

MELFORT RESEARCH STATION 
S. E. Beacom, B.Sc., M.Sc., Ph.D.

Forage Production, Harvesting and Utilization

D. A. Cooke, B.S.A., M.Sc. (Program Leader)

W. E. Coates, B.Sc., M.Sc., Ph.D.

D. H. McCartney, B.Sc., M.Sc.

J. A. Robertson, B.Sc., M.Sc., Ph.D.

S. 0. Thorlacius, B.Sc., M.Sc., Ph.D.

J. Waddington, B.Sc., M.Sc., Ph.D.
Director

Forage and pasture production

Forage harvesting systems

Pasture management

Beef cattle nutrition and forage utilization

Sheep nutrition and forage evaluation

Forage ecology and weed control

Cereal, Oilseed and Special Crop Production and Utilization

K. E. Bowren, B.S.A. (Program Leader)

A. G. Castel1, B.Sc., M.Sc., Ph.D.

W. F. Nutta11, B.S.A., M.Sc., Ph.D.

D. J. Warnock, B.S.A., M.Sc.
Tillage and cropping

Crop utilization (swine nutrition)

Soil fertility

Crop variety evaluation 
Management . . . . . . . . . . . . . . . . . 1

Forage Production . . . . . . . . . . . . . . 1

When to Put Animals on Pasture ............. . . 2

Stocking Rate .................... . . . 2

Removal of Livestock from Pasture . . . . . . . . . . 2

Pasture Clipping and Spreading Droppings . . . . . . . . 3

Fencing . . . . . . . . . . . . . . . . . . . 3

Anima 1 Management . . . . . . . . . . . . . . . . . 3

Effect of Pre-pasture Feeding Practices . . . . . . . . . 3

Rotational Grazing . . . . . . . . . . . . . . 4

Supplementary Feeding . . . . . . . . . . . . . . 5

Bloat . . . . . . . . . . . . . . . 8

Other Management Practices . . . . . . . . . . 8

ANNUAL PASTURES

Oat Pastures . . . . . . . . . . . . . . . . . 9

Varieties . . . . . . . . . . . . . . . . . 9 9

Management . . . . . . . . . . . . . . . 9

Advantages . . . . . . . . . . . . . . . 10

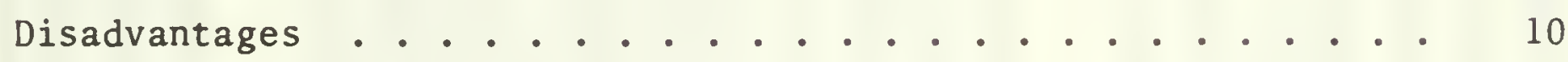

Animal Performance . . . . . . . . . . . . . . . 11

Steers...................... . . . 11

Lambs . . . . . . . . . . . . . . . . . 11 


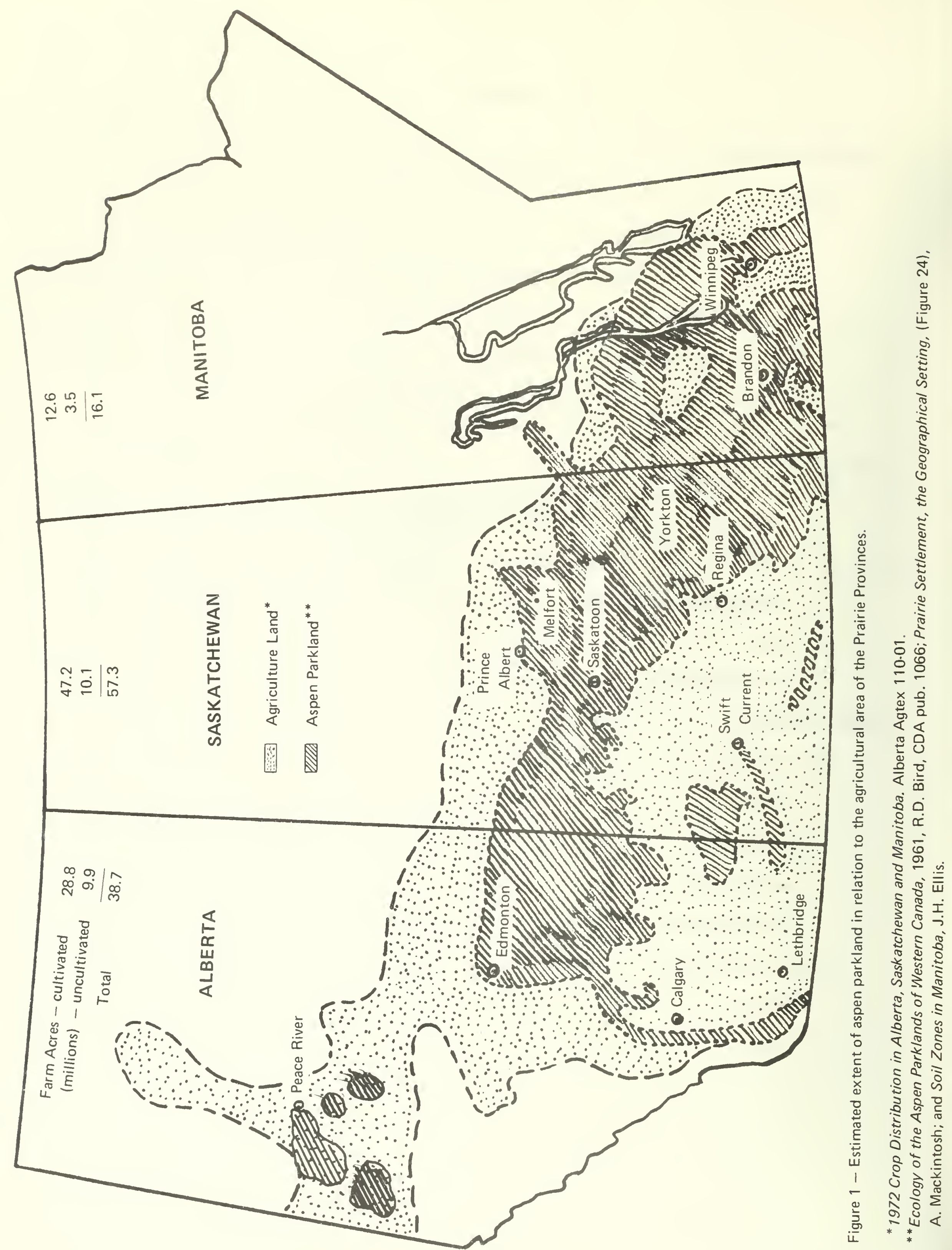


Dryland pasture production in the parkland area (Figure 1) varies considerably from spring to fall and from year to year. In an effort to increase and maintain forage productivity, the Melfort Research Station for a number of years has been conducting experiments to improve methods of pasture management. This publication gives the results of some of our work on both perennial and annual pastures.

\section{PERENNIAL PASTURES}

\section{MANAGEMENT}

\section{Forage Production}

Forage yields depend mainly on available moisture, temperature, soil fertility, and type of pasture management. In an experiment at Melfort, drymatter (DM) production of brome-alfalfa pastures in the first 7 years following establishment averaged $3660 \mathrm{lb} / \mathrm{ac}$, but varied from 1570 to $5120 \mathrm{lb} / \mathrm{ac}$ (Figure 2).

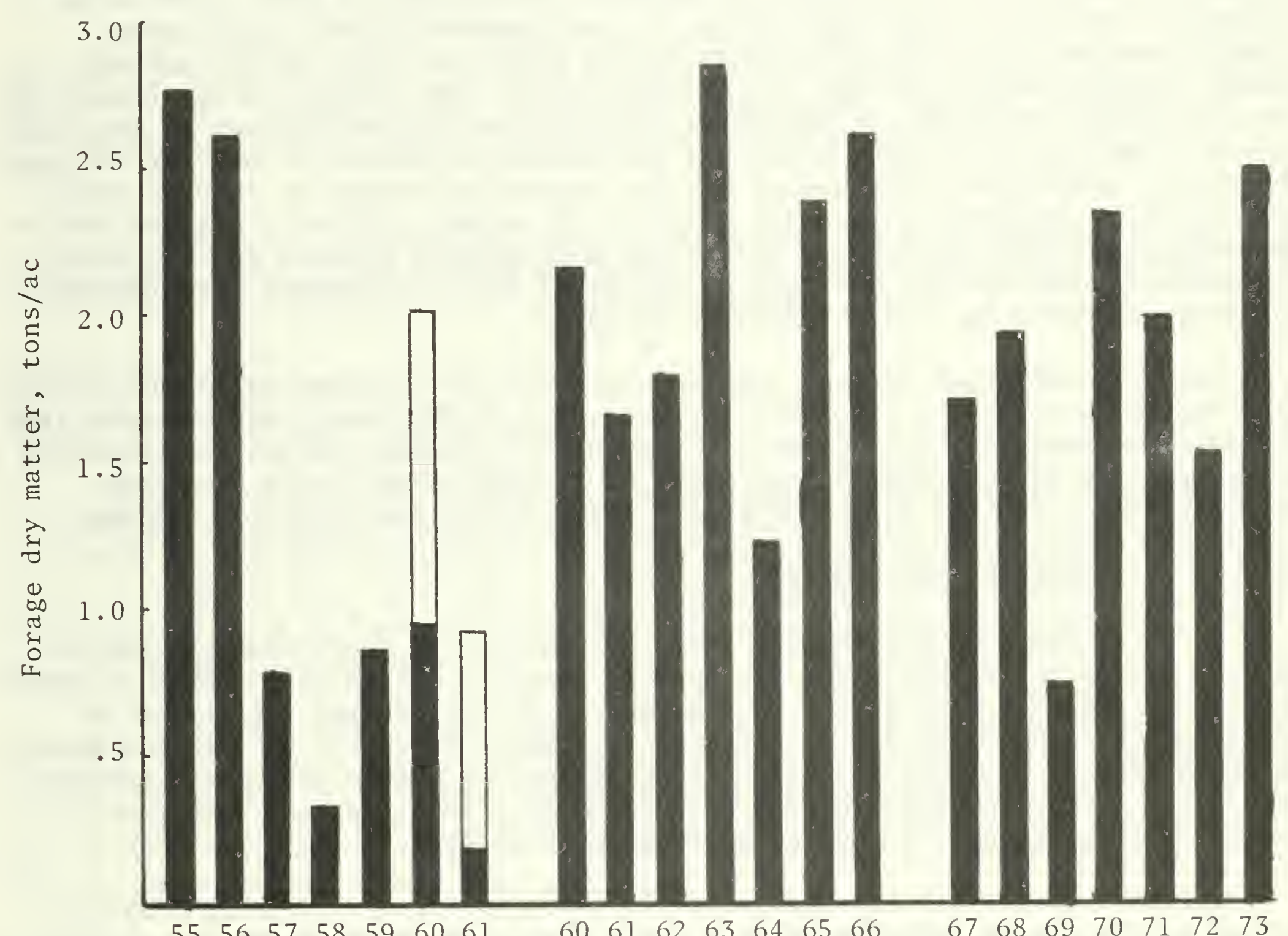

\section{Precipitation}

$\begin{aligned} & \text { Apr 1 - Aug 31 } \\ & \text { Oct } 1 \text { - June }\end{aligned}$
$\begin{aligned} & \text { Nitrogen, } \\ & \quad 11\end{aligned}$
$\quad 14$

Figure 2 - Brome-alfalfa pasture dry matter production, Melfort, 1955-73. 
Another variable is the seasonal nature of herbage growth. During the 7year experiment mentioned above, $70 \%$ of the total production occurred by the lst week of July. Since the nutrient requirements of livestock are relatively constant throughout the grazing season, plans for pasture managemont must allow for this seasonal variation in forage production.

When to Put Animals on Pasture

Pasture, especially alfalfa or clover, should not be grazed in the spring until the herbage has reached a height of 6-8 in. Most legumes require time to establish food reserves in the roots before being grazed or the plants may weaken and die. Some grasses, such as crested wheatgrass and Russian wild ryegrass, and the legume sainfoin commence growth in early May and can usually be grazed by the 3 rd week in May. Other forages, such as bromegrass, intermediate wheatgrass and alfalfa, are seldom ready for grazing until the lst week in June.

Stocking Rate

The variability in DM production of dryland pastures makes the choice of a suitable stocking rate difficult. At Melfort, production of $3000 \mathrm{lb} \mathrm{DM} / \mathrm{ac}$ is probably a realistic long-term average for an adequately fertilized bromealfalfa pasture. Stocking at the rate of one steer per acre, on the average, allows yearling steers to gain 2-2.5 lb/day during the grazing season (about 100 days). In years of above-average precipitation, some excess herbage is available to put up as hay or silage. Harvesting the surplus is practical only if the total pasture is subdivided into several fields. Harvesting should be done in early July to allow regrowth for grazing later in the season. If it is assumed that a DM yield of $3000 \mathrm{lb} / \mathrm{ac}$ provides sufficient good-quality pasture for one steer, the stocking rate for any area can be estimated from the average hay yield for the area, relative to that obtained at Melfort.

Once the long-term average stocking rate has been determined, modifications are required annually to allow for the variation in DM production. Assuming that the level of fertility is adequate, the amount of rainfall before the beginning of the grazing season (June 1) can serve as a rough guide to the carrying capacity of the pasture for the season, compared with the long-term average.

Removal of Livestock from Pasture

In rotational grazing systems, livestock have to be moved from pasture to pasture periodically throughout the season. Ideally, the animals should be moved when the growth has been grazed to a height of 3-4 in. During the period of rapid growth in June, it may be preferable to move the cattle before this point has been reached, so that all pastures can be grazed before the plants advance beyond the flowering stage. With a four-field rotational system, each field should be large enough to provide grazing for 7-14 days.

Unless a rotational grazing system is used, pastures containing alfalfa should not be grazed from September 1 until freeze-up. This allows the alfalfa to build sufficient food reserve in the roots to survive the winter and establish growth the following spring. Additional areas seeded to either crested wheatgrass or Russian wild ryegrass usually provide excellent grazing in late fall and allow the main pasture area to be rested. 
In spite of good management, grazing may be patchy on some fields, especially if a continuous grazing system is used. When this occurs, livestock tend to avoid the areas in which the herbage has matured and to overgraze the remaining area. Unevenly grazed pastures should be clipped to a uniform height, preferably shortly after the animals have been moved to another pasture. If this is not possible, clipping once a year either in late fall or early spring is advisable.

Urine patches and cattle droppings can also result in uneven grazing, as animals tend to avoid herbage growing close to either. Once dry, droppings can be broken up and spread by harrowing. Fertilization of the pasture largely eliminates unevenness caused by urine.

Fencing

A strong, wel1-constructed fence around the perimeter of the pasture is particularly important. One consisting of four strands of barbed wire or pagewire, with posts 16-18 ft apart, is recommended.

If rotational grazing is practiced, electric fences can be used to advantage for internal fencing. One strand of barbed or smooth 12-gauge wire, attached to steel posts 25-30 ft apart, is usually adequate. If 110-volt current is available, the high-voltage controllers are effective over several miles of fence.

For additional information, see bulletins $T-1$ and $T-54$, Pasture Fencing and Fence Post Preservation, available from the Family Farm Improvement Branch of the Saskatchewan Department of Agriculture, Regina.

\section{ANIMAL MANAGEMENT}

\section{Effect of Pre-pasture Feeding Practices}

Calves - Restricting the gain of calves during winter has sometimes been recommended to maximize low-cost gains on pasture the following summer. However, in the Melfort area the winter is long and the grazing season short. A 400-500lb calf requires about $8 \mathrm{lb} /$ day of medium-quality hay for maintenance. An additional 5-7 lb of feed could provide sufficient nutrients to produce a gain of approximately $1 \frac{1}{2} 1 \mathrm{~b} /$ day.

An experiment was carried out in which calves were wintered to gain at one of three rates - $0.5,1.0$ or $1.51 \mathrm{~b} /$ head per day - and subsequently placed on brome-alfalfa and oat pastures. The different rates of winter gain were obtained by feeding the same ration $(70 \%$ roughage and $30 \%$ grain plus a protein, mineral and vitamin supplement) at rates of about $9.5,12$ and $14.71 \mathrm{~b}$ of feed/head per day. The results are illustrated in Figure 3.

Rate of gain on pasture was inversely related to rate of winter gain. For every extra pound of gain put on during the winter, steers gained $0.51 b$ less during the pasture season (compared with those wintered to gain at the lowest rate). However, wintering to produce the higher rates of gain reduced the cost per pound of gain for the winter feeding period and resulted in a heavier, more valuable animal at the end of the grazing season. Therefore, if yearling steers 


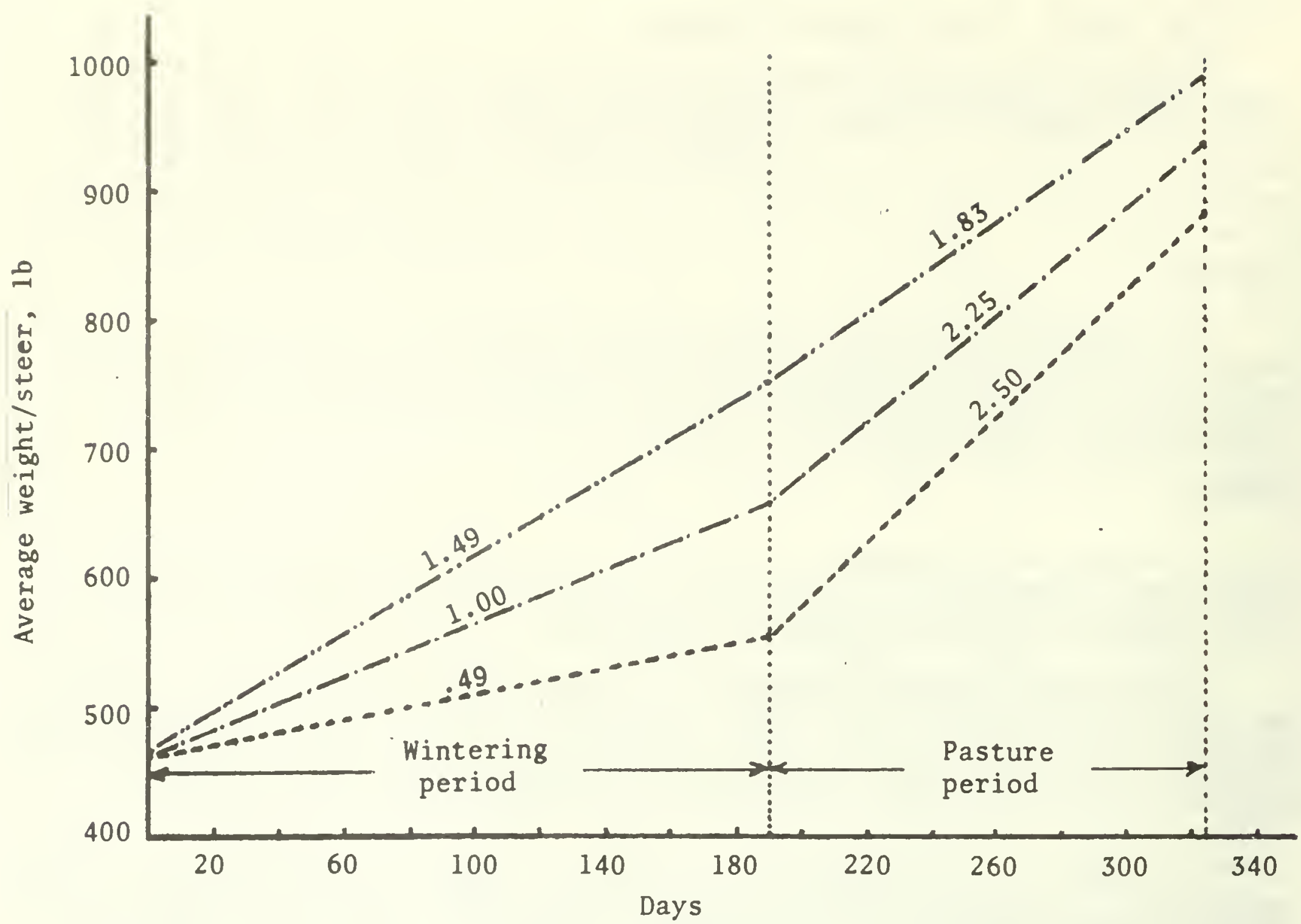

Pigure 3 - Effects of pre-pasture feeding practices on rate of gain of steers on pasture.

or replacement heifers are to be pastured, it is recommended that they be wintered to gain approximately $1.5 \mathrm{lb} /$ day. On the other hand, if you are buying cattle at the start of the pasture season, select those that show evidence of being wintered at a low rate of gain as, other things being equal, they will gain more on pasture than cattle wintered at a high rate of gain.

Pregnant Cows and Ewes - With a breeding herd or flock, winter feeding should provide just enough nutrients to maintain cows or ewes and produce strong, healthy offspring. Feeding more than is necessary during winter increases costs without producing any additional revenue. If sufficient pasture is provided during summer, the animals can be brought into good condition for breeding and maintained in good condition until the start of winter feeding.

\section{Rotational Grazing}

With yearlings, the objective of any grazing management system is to supply enough good-quality herbage to allow animals to gain rapidly throughout the season. Too often, much of the gain obtained during June and July is lost during August and September due to a shortage of pasture.

One way to improve both animal and pasture management is to practice rotational grazing. For this, the pasture area is subdivided into a number of fields 
about equal in size and separated by electric cross-fences, which are less expensive than conventional fencing.

An advantage of this system is that livestock graze more evenly if restricted to one portion of the pasture at a time; otherwise, they tend to overgraze or undergraze some areas. Rotational grazing also makes it easier for a pasture manager to assess the amounts of herbage consumed and in reserve and, thus, to decide if the stocking rate is adequate and whether or not there is surplus herbage that should be harvested for hay or silage. The main disadvantage of the system probably is the additional cost of cross-fencing and providing additional watering facilities.

Supplementary Feeding

The use of supplementary feed on pasture allows higher stocking rates and also allows rate of animal gain to be maintained at a more constant level, both from year to year and throughout a grazing season.

For the past 7 years, researchers at the Melfort Station have been comparing three methods of supplementary feeding of yearling steers on pasture with one in which stocking rate is adjusted to the herbage available (put-and-take). The methods include:

1. Maintaining a constant but low stocking rate and feeding back surplus pasture preserved as silage.

2. Maintaining a high stocking rate and supplementing with oat soilage during the latter half of the season.

3. Maintaining a high stocking rate and supplementing with rolled barley.

The barley was hand-fed beginning in early July. As the quantity and quality of pasture declined the allowance of grain was gradually increased from 2-3 1b/head per day until the steers were on self-feed. The objective of these pasture treatments is illustrated in Figure 4, where nutrient requirements of the animals are compared with the herbage available for grazing. The results, costs and returns of the 7-year experiment are summarized in Table 1.

Of the three supplementary feeding methods tested, barley has shown the most promise. In addition to allowing an increase in the stocking rate, feeding grain on pasture increased average daily gain and, in most years, many of the steers carried a sufficient degree of finish to grade Good or Choice by the end of the grazing season. During the period of the experiment, this method also gave the highest net return per acre (which was obtained by deducting the initial value of the steers and the supplementary feed costs from the final value of the steers). However, at current (1974) values for grain and feeder cattle, feeding supplementary barley would produce lower net returns than the supplementary oat soilage treatment.

The oat soilage treatment also allowed an increased stocking rate and maintained animal gain at an average of $2 \frac{1}{4} \mathrm{lb} /$ day. To maintain a supply of oat soilage of good quality, three or four sowings at 2-3-week intervals beginning in late May are necessary. A forage harvester and either a self-loading wagon or a wagon that can be used as a self-feeder are required. If oats are to be used, it may be more practical to completely graze the permanent pasture area 


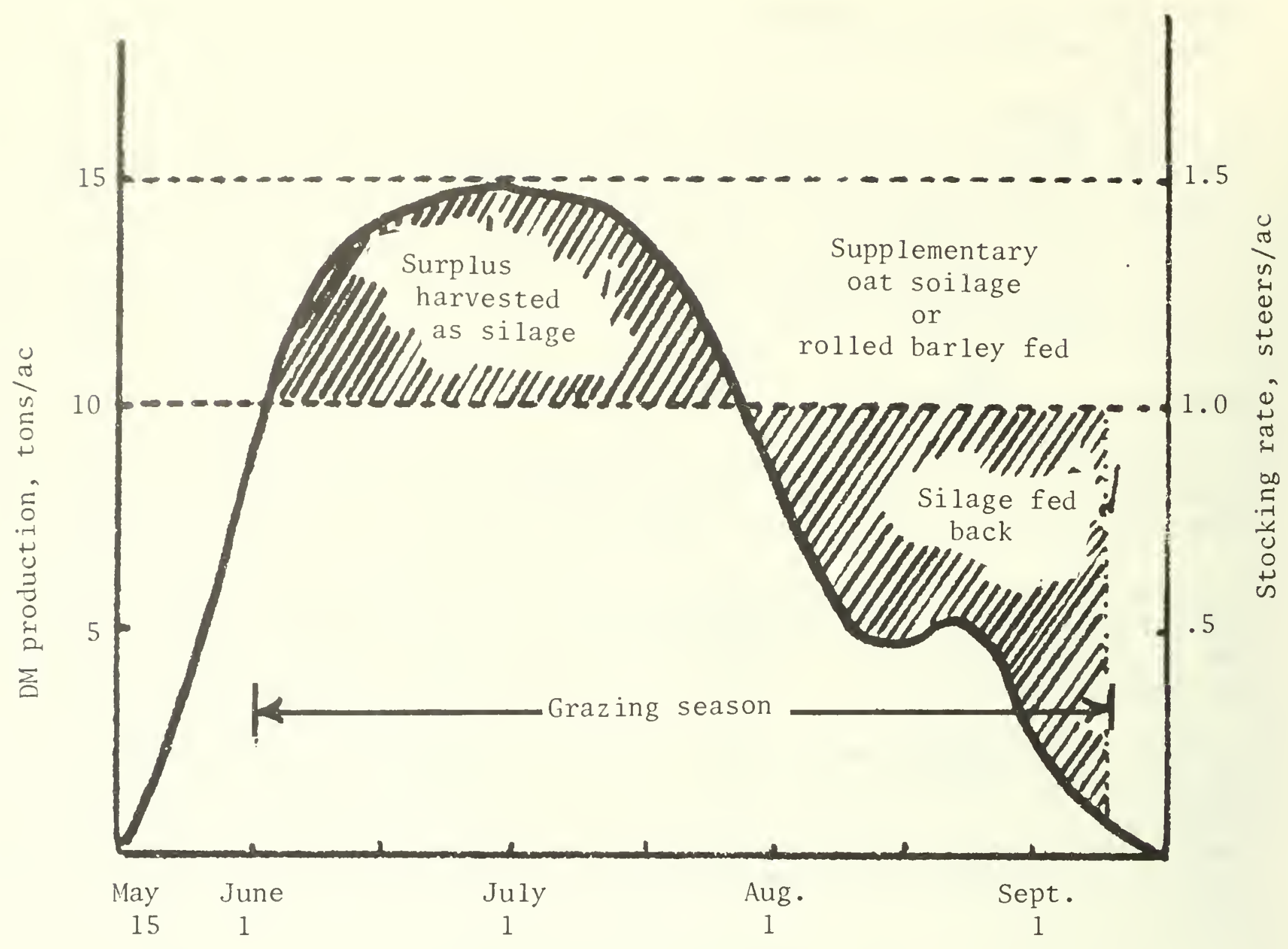

Figure 4 - Comparison of nutrient requirements of steers with herbage available for grazing.

and then to either graze the oat pasture or to move the cattle into drylot and zero-graze the oats.

The pasture plus silage method has allowed an almost constant stocking rate throughout the season, but at a lower level than for the treatments in which supplementary barley or oat soilage were fed. Also, the net return per acre was well below that obtained from the treatments in which supplementary feeding was practiced.

The put-and-take method (stocking rate adjusted to pasture supply) is an efficient way of utilizing the herbage. However, under this system, many of the animals must be removed during the latter part of July and August and may have to be sold at a time when other cattle are coming off pasture and prices are low, or be finished in the feedlot during a busy season of the year. Table 1 shows that the returns for this method of management were lower than for any of the methods with supplemental feeding.

Research results suggest that if grain is fed on pasture, a daily allowance of $0.5-1 \%$ of body weight fed during the early part of the season will increase rate of gain. Feeding more than this amount when the pasture is still in a lush 
Table 1 - Supplementary Feeding on Pasture

\begin{tabular}{|c|c|c|c|c|}
\hline Treatment & $\begin{array}{l}\text { Put-and-take } \\
\text { method }\end{array}$ & $\begin{array}{c}\text { Pasture and } \\
\text { silage }\end{array}$ & $\begin{array}{l}\text { Pasture and } \\
\text { oat soilage }\end{array}$ & $\begin{array}{l}\text { Pasture and } \\
\text { rolled barley }\end{array}$ \\
\hline No. of steers on test (24 ac) & 36 & 24 & 35 & 35 \\
\hline Av. initial wt, $1 b$ & 695 & 697 & 694 & 695 \\
\hline No. of steers off test & 15 & 20 & 31 & 31 \\
\hline Av final wt, $1 \mathrm{~b}$ & 950 & 958 & 947 & 993 \\
\hline $\begin{array}{l}\text { Av stocking rate, steers/ac } \\
\text { Range in stocking rates, }\end{array}$ & 1.05 & .97 & 1.35 & 1.36 \\
\hline steers/ac & $1.59-.62$ & $1.22-.62$ & $1.56-1.12$ & $1.58-1.12$ \\
\hline Av daily gain, $1 \mathrm{~b}$ & 2.23 & 2.27 & 2.23 & 2.64 \\
\hline Liveweight gain/ac, Ib & 244 & 252 & 333 & 389 \\
\hline DM produced/ac, $1 \mathrm{~b}$ & 3394 & $\begin{array}{l}3677 \\
\text { ncludes silag }\end{array}$ & ge) 3787 & 3796 \\
\hline DM consumed/ac, $1 \mathrm{~b}$ & 2898 & $\begin{array}{r}3004 \\
\text { ncludes silag }\end{array}$ & ge) 3211 & 3204 \\
\hline Supplementary DM fed/ac, lb & (i) & $\begin{array}{r}484 \\
\text { ncluded above }\end{array}$ & 889 & 1031 \\
\hline $\begin{array}{l}\text { Days of supplementary feeding } \\
\text { Supplementary DM fed/steer/day, }\end{array}$ & 0 & 37 & 55 & 75 \\
\hline $1 b$ & 0 & 14.0 & 13.3 & 10.4 \\
\hline
\end{tabular}

Costs and returns (1974 estimate)

\begin{tabular}{|c|c|c|c|c|}
\hline $\begin{array}{l}\text { Cost of steers a } 40 \$ \text { ( } 4 \% \text { shrink) } \\
\text { Cost of buying and trucking }\end{array}$ & $\$ 9,523.52$ & $\$ 6,688.99$ & $\$ 9,478.72$ & $\$ 9,699.43$ \\
\hline $85 \$ /$ cwt & 202.37 & 142.14 & 201.42 & 206.11 \\
\hline $\begin{array}{l}\text { ost of supplemental feed } \\
\text { (air-dry basis) }\end{array}$ & & & & \\
\hline - silage@ $3 / 4 \$ / 1 b$ & & 96.80 & & \\
\hline - green oats e $2 \$ / 1 b$ & & & 474.13 & \\
\hline - barley @ $5 \phi / 1 b$ & & & & $1,374.67$ \\
\hline st. investment in pasture & & & & \\
\hline equipment (includes interest) & & & & 54.00 \\
\hline alue of cattle sold & & & & \\
\hline - light feeders @ $43 \$$ & $6,773.76$ & 1.729 .17 & $1,412.43$ & $1,341.56$ \\
\hline - heavy feeders @ $46 \$$ & $6,294.65$ & $8,522.42$ & $12,902.23$ & $14,057.42$ \\
\hline Cost of marketing @ $\$ 1.10 / \mathrm{cwt}$ & 339.63 & 248.03 & 344.66 & 370.48 \\
\hline Cost of pasture @ $\$ 25 / a c$ & 600.00 & 600.00 & 600.00 & 600.00 \\
\hline & & & & \\
\hline 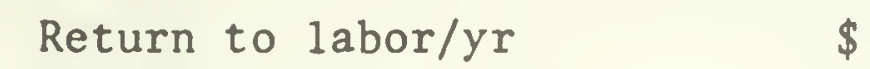 & 2,40 & $2,475.63$ & $3,215.73$ & $3,094.29$ \\
\hline Return to labor/ac & 100.12 & 103.15 & 133.99 & 128.93 \\
\hline
\end{tabular}

condition results in poor utilization of the pasture and little or no additional gain compared with that obtained on pasture alone. Grain intake can be restricted either by hand-feeding or by the addition of salt to the rolled grain. A level of $10 \%$ salt in the grain mixture will limit intake to about $6 \mathrm{lb} /$ head per day. If salt is used as a method of controlling intake, ample quantities of water should be available within a short distance of the feeders. As soon as herbage consumption exceeds herbage production (usually during the latter part of July), the amount of grain fed can be increased gradually. By the end of the grazing season 
the animals are accustomed to consuming large quantities of grain and, if not completely finished, can be placed in a feedlot on full feed until ready for market. There is some additional risk associated with the feeding of grain, because of increased incidence of bloat, but with reasonable care this risk can be minimized.

Bloat

On pastures containing grass-alfalfa or grass-clover mixtures, there is a risk of bloat. This risk is usually greater on regrowth in August. Observe these general precautions:

1. Keep legume content of the pasture to less than $50 \%$ (by weight) of the total dry matter.

2. Avoid grazing pastures after rain or a heavy dew, if possible.

3. Provide supplementary grass or oat hay.

4. Cull bloat-prone animals before losses occur.

Unfortunately, none of these precautions provide complete protection. When bloat occurs, animals should be drenched. This can be done orally by means of either a long-necked bottle or a pump stomach tube. A number of commercial bloat preparations are available. Mineral or vegetable oils are usually effective. Walking a bloated animal may help to initiate belching.

The legume sainfoin does not cause bloat and the variety Melrose is sufficiently winter-hardy for the parkland belt of Western Canada. Although more information is required concerning the management of this crop, it appears to be promising as a nonbloating pasture legume.

\section{Other Management Practices}

Minerals - Grazing animals require supplementary minerals. Cobalt-iodized salt should always be available free-choice. In addition, a mixture containing $70 \%$ of a calcium phosphorus supplement (such as bone meal or calcium phosphate) and $30 \%$ cobalt-iodized salt is advised. Some commercial mineral mixtures contain a small quantity of molasses to improve palatability.

Growth Stimulants - Implants such as Synovex and Ralgro are widely used for finishing cattle in feedlots and can be equally effective when used for growing and finishing cattle on pasture. Synovex-S is suitable for implanting steers and Synovex-H is intended for use with heifers but should be used only on heifers being grown for slaughter. When placed on pasture at a weight of about $7001 \mathrm{~b}$, steer calves implanted with Synovex-S gained $0.55 \mathrm{lb} /$ day more over the grazing season than similar unimplanted steers.

Control of Flies - Flies and mosquitoes can cause considerable discomfort to animals on pasture and may reduce rate of gain. Among the worst offenders are the stable fly, which tends to attack the legs, and the horn fly, which congregates in clusters on the withers. Horse flies are occasionally a problem and blackflies may be a pest in pastures adjacent to streams and rivers. 
Although no long-lasting fly repellants are available, a number of insecticides provide some relief from flies. These include Ciodrin 20, Methoxychlor ( $50 \%$ wettable powder), Ronnel and carbaryl (Sevin). The usual methods of application are as a high-pressure spray or by back rubber. Follow manufacturers' directions when using insecticides.

Vaccination - Blackleg and malignant edema are two infectious diseases for which cattle should be vaccinated. Vaccination is very effective and should be done at 3-4 months of age and again at 1 year. The dose recommended by the manufacturer should be given subcutaneously.

\section{ANNUAL PASTURES}

In drier areas of the parkbelt, the use of annual pastures is recommended to stabilize production and extend the pasture season. When moisture is limiting for several years in a row, a long-term, grass-legume stand can become very unproductive whereas a cereal crop grown after fallow could yield reasonably well. Sometimes cover crops are required to control erosion and these can be a useful source of pasture when fencing and the provision of water do not present problems.

\section{OAT PASTURES}

The best annual pasture for northern Saskatchewan is oats. Research at Melfort has shown that good oat pastures extend the grazing season by as much as 40 days. This often enables the livestock producer to produce finished beef that can be marketed off pasture. Areas not required for grazing can be harvested for silage, oat hay or grain.

\section{Varieties}

Varieties developed for grain production, such as Garry and Rodney, were used in most of the studies with steers. In lamb tests between 1970 and 1972, the grain variety Fraser gave the best overall results when compared with two other grain varieties (Harmon and Kelsey) and a potential forage oat variety (0A-123-1). In a 1973 test with lambs, Fraser was compared with another forage oat selection (IH 1863-4) and two feed wheats (Pitic 62 and Glenlea). Fraser again gave the highest gains, although both the forage oat and Pitic 62 produced higher yields of dry matter.

\section{Management}

The following procedure is suggested:

1. Select a field that is to be summerfallowed and divide it into four areas. Important considerations are ease of access, fencing (electric is recommended) and water supply.

2. Have a soil test done to determine fertilizer requirements; otherwise, apply a fertilizer such as 23-23-0 with the seed at not less than $70 \mathrm{lb} / \mathrm{ac}$.

3. Seed one area about mid-May, if oats are to be the sole supply of pasture; or later (about mid-June, depending on expected date required), if oats are to supplement perennial pastures. Seed $70 \mathrm{lb} / \mathrm{ac}$. Seed remaining areas at intervals of 10-14 days, for a continuing supply of oat pasture throughout the summer. 
This also allows for rotational grazing, as oats recover well and may be grazed three times in a season.

4. Commence grazing when oats are 9-10 in. high. If oats are grazed earlier cattle may scour.

5. Move cattle when oats have been grazed down to 3-4 in. Rotate them quickly enough to avoid any marked change in the quality of the pasture. As oats mature, feeding value is still good but trampling causes excessive wastage.

\section{Advantages} pasture.

1. An oat pasture is usually easier to establish than a grass-legume

2. It supplements and extends the grazing season. Oats are ready for grazing 4-6 weeks after seeding and can be grazed until freeze-up.

3. From 40 to 60 steer-days of grazing per acre can be obtained, depending on yield and stocking rate.

4. Dry matter yields are good (3400 to $5300 \mathrm{lb} / \mathrm{ac}$ at Melfort).

5. Animal gains are good. Implanted steers of good quality and condition should gain about $2 \frac{1}{2} \mathrm{lb} /$ head daily. Well managed oat pastures, used throughout the grazing season for lamb production, have produced liveweight gains of over $500 \mathrm{lb} / \mathrm{ac}$.

6. Steers can be rotated between oat and grass-legume pastures without suffering digestive disturbances, provided the stage of growth is similar on both pastures.

7. Allows steers to be finished on pasture or to at least maintain a high rate of gain without being fed grain.

Disadvantages

1. Crop has to be seeded each year; a wet spring could seriously delay pasture production.

2. Wastage can range from $20-60 \%$, depending on stocking rate, height and density of the stand, etc.

3. Liveweight gain per acre is relatively low when cattle are placed on heavy stands late in season (120-150 lb depending on crop yield and extent of wastage).

4. Nitrate poisoning may be a problem following periods of slow growth due to frost or drought. Levels of nitrate in the plant may be increased by high levels of nitrogen in the soil. Symptoms of poisoning are abdominal pain, diarrhea and vomiting; rapid breathing or gasping; muscle tremor, weakness, staggering gait; and severe cyanosis (turning blue). Death usually occurs 12-24 hours after eating the high-nitrate feed, if treatment is not initiated quickly. Treatment consists of injecting a $1 \%$ solution of methylene blue into the blood stream to provide about $1 \mathrm{mg}$ of the chemical for each pound of body weight. 
(For example, a $900-1 \mathrm{~b}$ steer would require $90 \mathrm{cc}$ of a solution made by adding 45 gm ( $1 / 10$ lb) methylene blue to 1 gal distilled water).

The danger of nitrate poisoning on oat pasture is often greatly exaggerated, however, and does not come close to outweighing the advantages to be gained by using oat pastures either to supplement perennial pastures or as the sole pasture for growing-finishing cattle. No problems have been encountered at Melfort, even when steers consumed forage containing slightly over $2 \%$ nitrate. To be safe, plants should contain less than $1.5 \%$ potassium nitrate (this is equivalent to about $1 \%$ nitrate). If in doubt, send a representative sample of oat forage to your nearest feed laboratory for a nitrate analysis.

\section{ANIMAL PERFORMANCE}

\section{Steers}

Mechanical Grazing - When oat pastures were cut daily with a forage harvester and the green chop was fed to steers in drylot, the liveweight gain per acre increased from 129 to $312 \mathrm{lb}$ (almost $2 \frac{1}{2}$ times). Average daily gains, on the other hand, were reduced slightly, perhaps because the steers preferred chopped material to shredded material. Therefore, it may be desirable to use the cutter type rather than the flail type of forage harvester. Mechanically harvesting oat pastures greatly increases the efficiency of utilization, but other factors such as increased labor and equipment costs have to be considered. Perhaps a haylage type of operation would be the answer if a low-cost storage unit could be built.

Lambs

In the 1971-72 lamb experiments (mentioned under Varieties), liveweight gains per acre compared very favorably with gains obtained on other pastures. Giving the lambs access to a creep feed (cracked wheat, rolled oats and barley, and supplements) on the oat pasture increased gains considerably.

The two-field (each $0.23 \mathrm{ac}$ ) rotational grazing system used in these experiments was not adequate to provide continual grazing for three ewes and six or seven lambs throughout the season. It is therefore recommended that a larger acreage (by about $50 \%$ ) and at least a three-field rotational system be used to ensure a continual supply of forage and allow for better grazing management. 



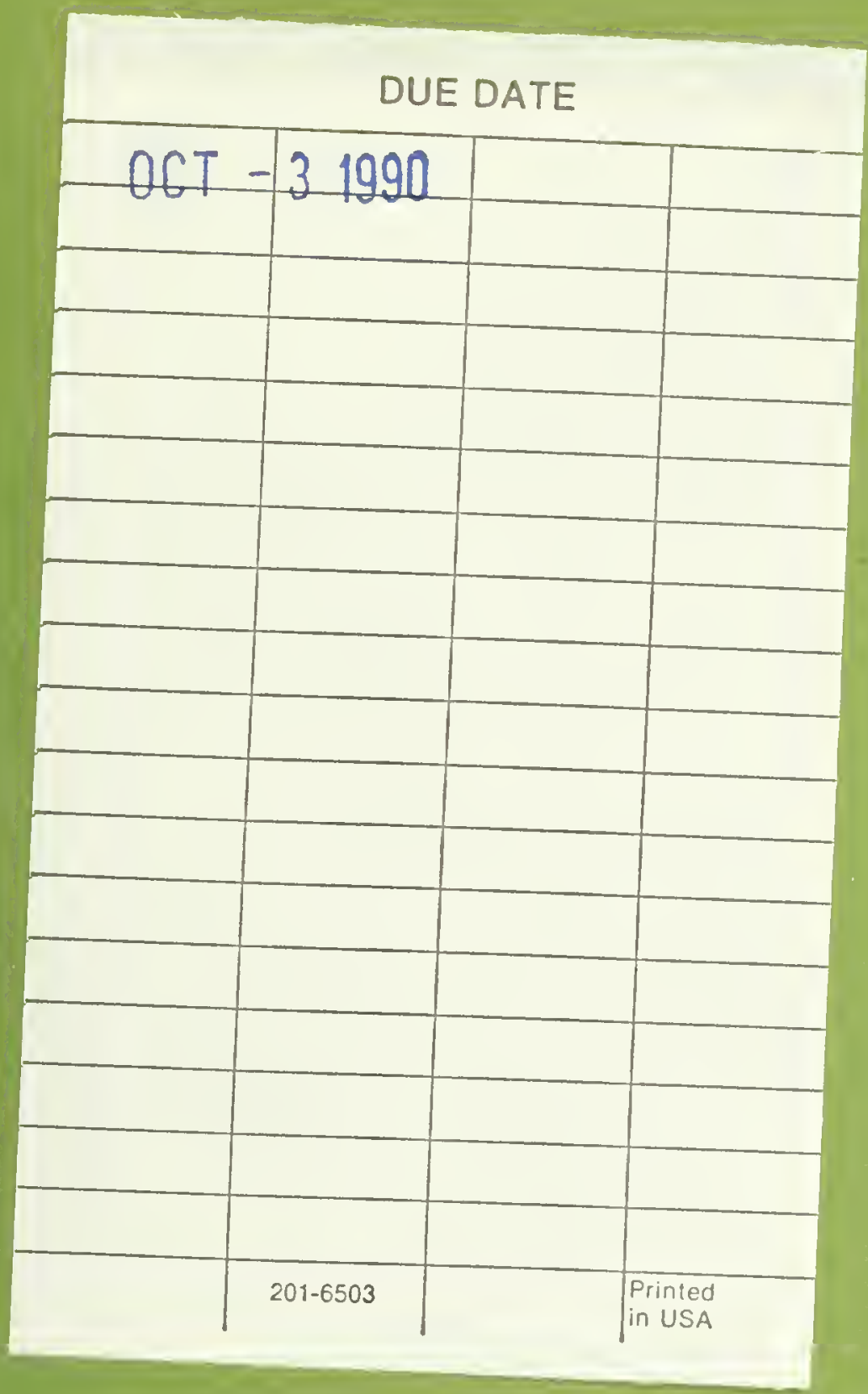
H||

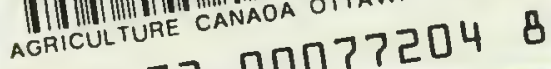
390730007 
INFORMATION

Edifice Sir John Carling Building

930 Carling Avenue

Ottawa, Ontario

K1A OC7

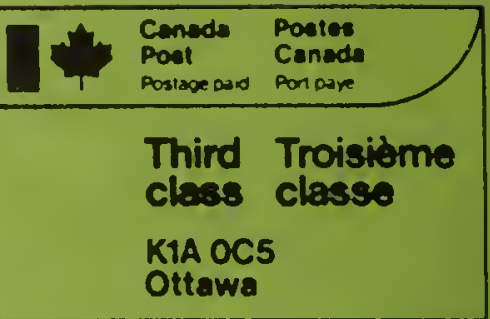

